\title{
短緸維混入補強土のカ学特性に及ほすファイバー形状の影響
}

$\begin{array}{cccc}\text { 日本大学大学院 } & \text { 学生員 } & \text { ○仲原 } & \text { 寛昭 } \\ \text { 日本大学理工学部 } & \text { 正会員 } & \text { 巻内 } & \text { 勝彦 } \\ \text { 同上 } & \text { 正会員 } & \text { 峯岸 } & \text { 邦夫 }\end{array}$

概要 :

補強土工法の土塊を内部から補強（土粒子の変形拘束）する工法の一つに, 短繊維混合補強土工法 がある。この工法は, 安定性を欠く原位置土や現場発生土の有効利用に際して, 有限長の短繊維(ファ イバー）を覮汼・混合することにより新しい土質性状の特性を付与し，より優れた土質材料を作り出 寸補強土技術である。この短繊維混入補強土については, 補強原理や影響要因などの研究が十分に明 らかにされていない部分も多い。

そこで本研究では,カオリン粘土と豊浦砂の混合土を試料土としてナイロン繊維の補強材の形状(繊 維長, 繊維径) の変化が, 補強メカニズムに及ぼす影響を調べるために, 一面せん断試験, 一軸圧縮 試験を行いその結果について報告する。

キーワード: ファイバー, 短纎維混入補強土, 一面せん断試験, 一軸圧縮試験, 強度定数

\section{Effects of Fiber Shape on Mechanical Properties of Short Fiber-Reinforced Soil $\mathbf{B y}$}

\author{
Hiroaki NAKAHARA,Katsuhiko MAKIUCHI \& Kunio MINEGISHI \\ (College of Science \& Technology, Nihon University)
}

Abstract:

A short length fiber-reinforced soil is classified as one of the fiber reinforced earth construction methods. The dispersed fibers within the soils confine the deformation movement of soil particles. These fiber reinforced earth methods can be employed for the effective usage of unstable in-situ soils and problematic disposal geotechnical materials, and be able to add new and surplus properties to the original soil. However the reinforcement mechanism and their influence factors of the short length fiberreinforced soil are not sufficiently revealed so far.

In this study, the effects of length and diameter of nylon-fiber reinforcements on mechanical characteristics of Toyoura sand, Kaoline clay and their mixtures are investigated using both shear box testing and unconfined compression testing.

Keywords : Fiber, Short fiber - Reinforced soil, Box shear test, Unconfined compression, Strength parameter 


\section{短緸維混入補強土のカ学特性に及ぼすファイバー形状の影響}

$\begin{array}{cccc}\text { 日本大学大学院 } & \text { 学生員 } & \text { ○仲原 } & \text { 寛昭 } \\ \text { 日本大学理工学部 } & \text { 正会員 } & \text { 巻内 } & \text { 勝彦 } \\ \text { 同上 } & \text { 正会員 } & \text { 峯岸 } & \text { 邦夫 }\end{array}$

1 はじめに

纎維混入補強土工法は, 土中にファイバーを混入させ土粒子の変形を内部拘束することにより補強する もので, 連続長繊維方式と短繊維方式に大別される。一般に繊維長が長いほど補強効果が高いとされてい るが, 補強メカニズムに及ぼす繊維径, 繊維長, 混入方式, 混入率などの定量的関係は十分明らかにされ ていない。

短繊維混入補強土工法は, 原位置土 や現地発生土に有限長の短繊維を均一

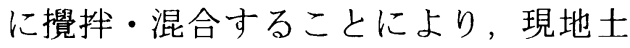
の土質性状と異なる所望の特性を付与 し，地盤材料を人工的に制御し造り出 す補強土技術である。

本研究では, 一面せん断試験および 一軸圧縮試験により，比較的纎維長の 短い場合のファイバー混合土について, 混入率一定条件下におけるファイバー 補強材形状の変化が補強メカニズムに 及ぼす影響を調心゙考察した。

表一1 一面せん断試験における補強材の形状

\begin{tabular}{|c|c|c|c|}
\hline 試料土名 & 織維長 L （cm) & 繊維径 $\mathrm{d}(\mathrm{mm})$ & 混入率(\%) \\
\hline \multirow{6}{*}{ 豊浦砂 : S } & \multirow{3}{*}{1.0} & 0.175 & \multirow{6}{*}{1.0} \\
\hline & & 0.330 & \\
\hline & & 0.660 & \\
\hline & 0.5 & \multirow{3}{*}{0.330} & \\
\hline & 1.0 & & \\
\hline & 2.0 & & \\
\hline
\end{tabular}

表－2 一軸圧縮試験における補強材の形状

\begin{tabular}{|c|c|c|c|}
\hline 試料土名 & 織維長 L $(\mathrm{cm})$ & 織維径 $\mathrm{d}(\mathrm{mm})$ & 混入率 $(\%)$ \\
\hline \multirow{9}{*}{$S+K$} & \multirow{3}{*}{ ( } & 0.175 & \multirow{9}{*}{1.0} \\
\hline & & 0.330 & \\
\hline & & 0.660 & \\
\hline & 0.5 & \multirow{6}{*}{0.330} & \\
\hline & 1.0 & & \\
\hline & 2.0 & & \\
\hline & 4.0 & & \\
\hline & 8.0 & & \\
\hline & 16.0 & & \\
\hline
\end{tabular}

\section{2 試料および試験方法}

\section{2-1 試料}

\section{（1）土質材料}

本研究で用いた試料土は, 気乾状態 の豊浦砂（略称：S）および一軸圧縮試 験の供試体作製時に自立可能な粘着力 成分を有する土として，カオリン粘土 （略称：K）を乾燥質量割合で $10 \%$ 混合 した豊浦砂十カオリン粘土 (略称: S + K）の 2 種類である。

\section{（2）補強材}

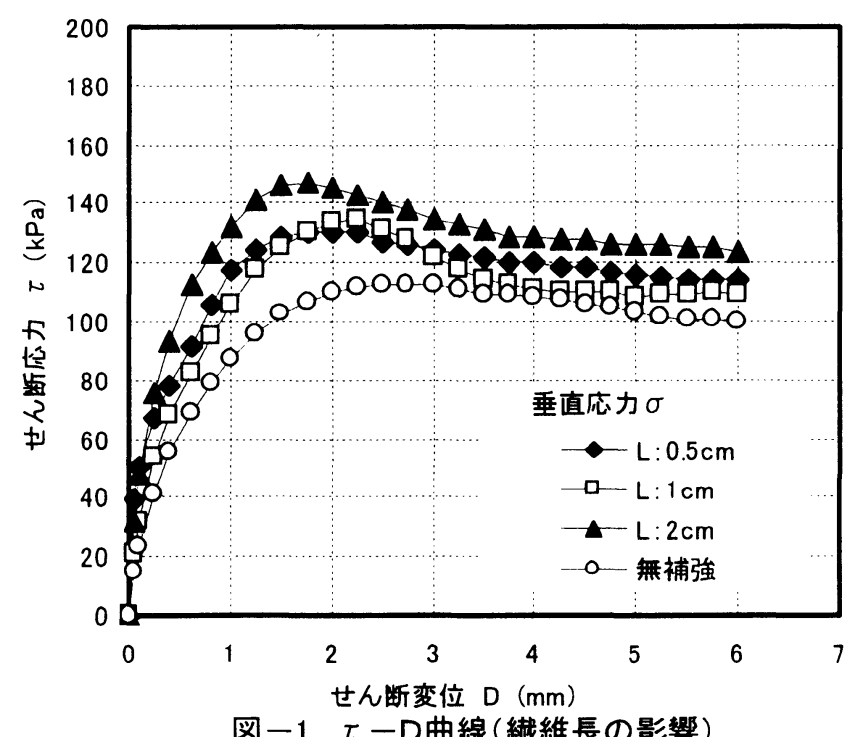


短繊維補強材には, ナイロン繊維(市販され ている釣り系を転用) を用いた。補強材の形状 (長さと直径) および混入率は, 一面せん断試験 の場合は表 -1 , 一軸圧縮試験用の場合は表一 2 に示す。

\section{2-2 試験方法}

\section{（1）供試体作製}

一面せん断試験においては，直径 $60 \mathrm{~mm}$, 高 さ $20 \mathrm{~mm}$ のせん断箱に気乾状態の豊浦砂と補強 材を均質に混ぜ，所定の密度（ $\rho_{\mathrm{d}}=1.43$ $1.45 \mathrm{~g} / \mathrm{cm}^{3}$, D r $=45 \sim 55 \%$ ）に詰めて成形 した。一軸圧縮試験においては, 締固め試験に より求めた最適含水比 $9.5 \%$ に調整した試料土 と補強材を均一に混合させ静的締固めエネル

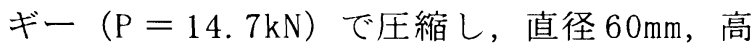
さ $140 \mathrm{~mm}$ の供試体 $\left(\rho_{\mathrm{d} \max }=1.74 \mathrm{~g} / \mathrm{cm}^{3}\right)$ を作 製した。

\section{（2）せん断試験}

一面せん断試験は, 変位速度 $0.25 \mathrm{~mm} / \mathrm{min}$ で せん断し，せん断応力とせん断変位の関係お よび強度定数の内部摩擦角 $\phi$ を求めた。また, 一軸圧縮試験は，圧縮ひずみ速度 $1.0 \% / \mathrm{min}$ で行い, 圧縮応力と軸ひずみの関係, 最大圧縮 応力, 残留強度を調心゙た。

\section{3 試験結果}

\section{3-1 一面せん断特性}

補強材混入率が一定の場合の豊浦砂に対して 図一 1 は繊維長, 図 -2 は繊維径が異なる場 合の一面せん断試験のせん断応力とせん断変 位の関係を示したものである。

図ー1より，繊維を混入することにより， せん断抵抗に対する補強効果が得られることが 分かる。繊維長が大きくなるに伴いせん断応 力の最大值および残留強度が上昇する傾向が認 められる。これは, 砂粒子と補強材の表面の界
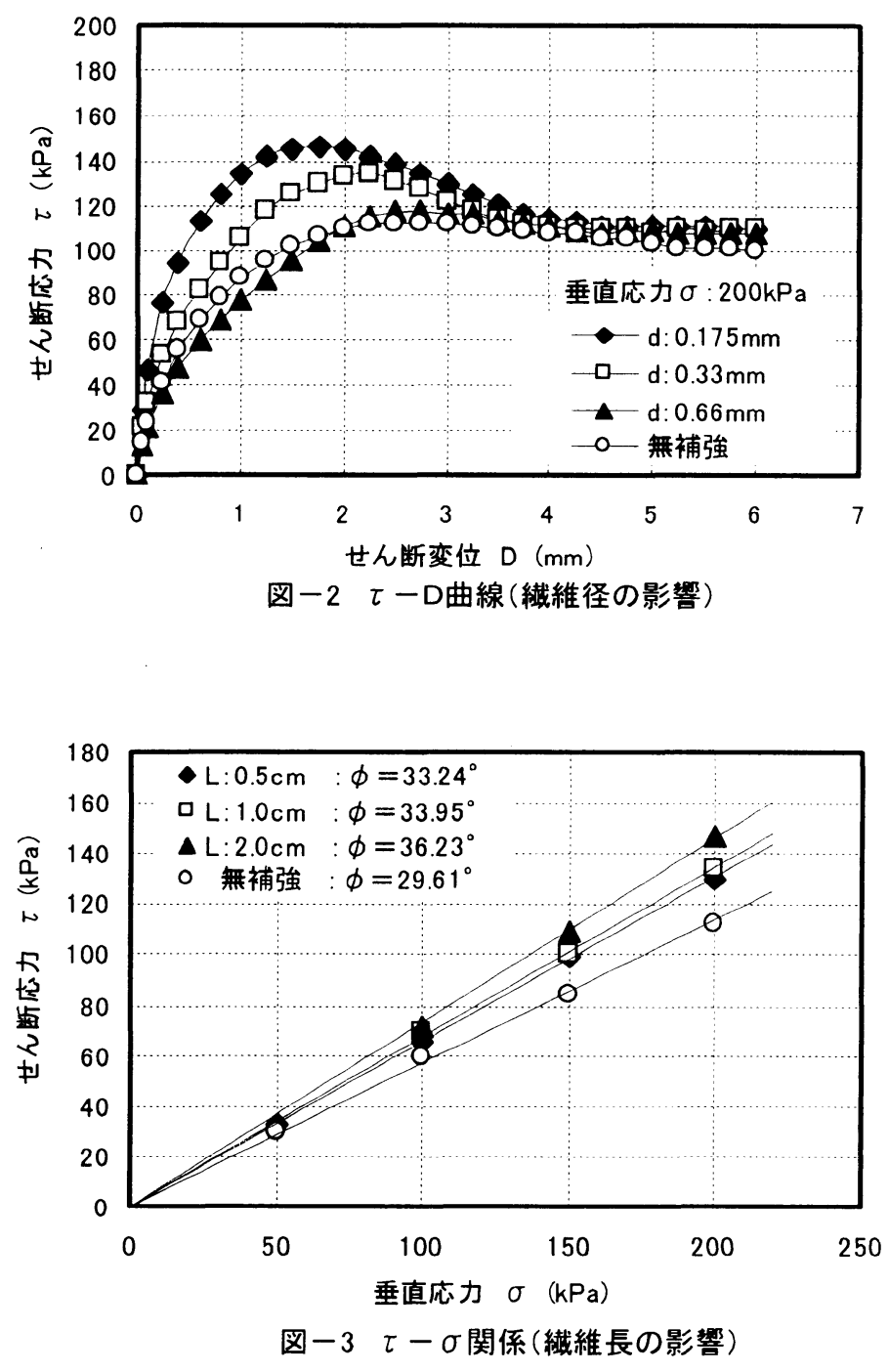
面摩擦抵抗とそれに起因するインターロッキング 作用などの拘束が生じているためと考えられる。 また, せん断ゾーンにおいて長い補強材ほど抵 抗領域を広範囲に拡大するため, 供試体全体に 強度ピーク時だけでなく残留強度の補強効果を波 及させると考えられる。

図一2では，繊維径が小さくなるに伴い，せ ん断応力は高くなる傾向が見られる。これは, 同 一混入率においては繊維径が小さくなるほど数 多くの補強材が分散されること，および摩擦に 寄与する表面積が増加するためと考えられる。 また, 初期における強度発現は, 緎維径が太く なるに伴い低下することが認められる。これは, 今回の実験では繊維径が太くなると砂と繊維の 十分な絡み合いに必要な補強材料の量が不足する ためと考えられる。

困一 3 は繊維長, 図一 4 は繊維径が異なる場 合のせん断応力と垂直応力の関係を示したもの である。また，図一 5 ，図一6 は内部摩擦角之 繊維長，繊維径の関係を示している。

図一 3 , 図一 5 より補強材の混入により無補 強に比心゙て内部摩擦角が高まり補強効果が向上 することが分かる。また，繊維長が大きくなる に伴いその効果も増加する傾向にある。これは, 補強材と土粒子との摩擦抵抗の連続性に加え, 繊維長が大きくなると，より多くの繊維同士お よび砂による絡み合いの領域が増加するためと 考えられる。

図一 4, 図-6より, 繊維径が大きくなると, 内部摩擦角が無補強時と等しく補強効果があまり 得られていないことが分かる。繊維径が小さい 場合は内部摩擦角が大きくなり補強効果が得ら れている。これは, 絨維径が小さくなるほど繊 維と砂の接触面積の増加に起因する摩擦抵抗が 増大するものと考えられる。すなわち，供試体 内での繊維の分散度が低下寸ると補強効果が得
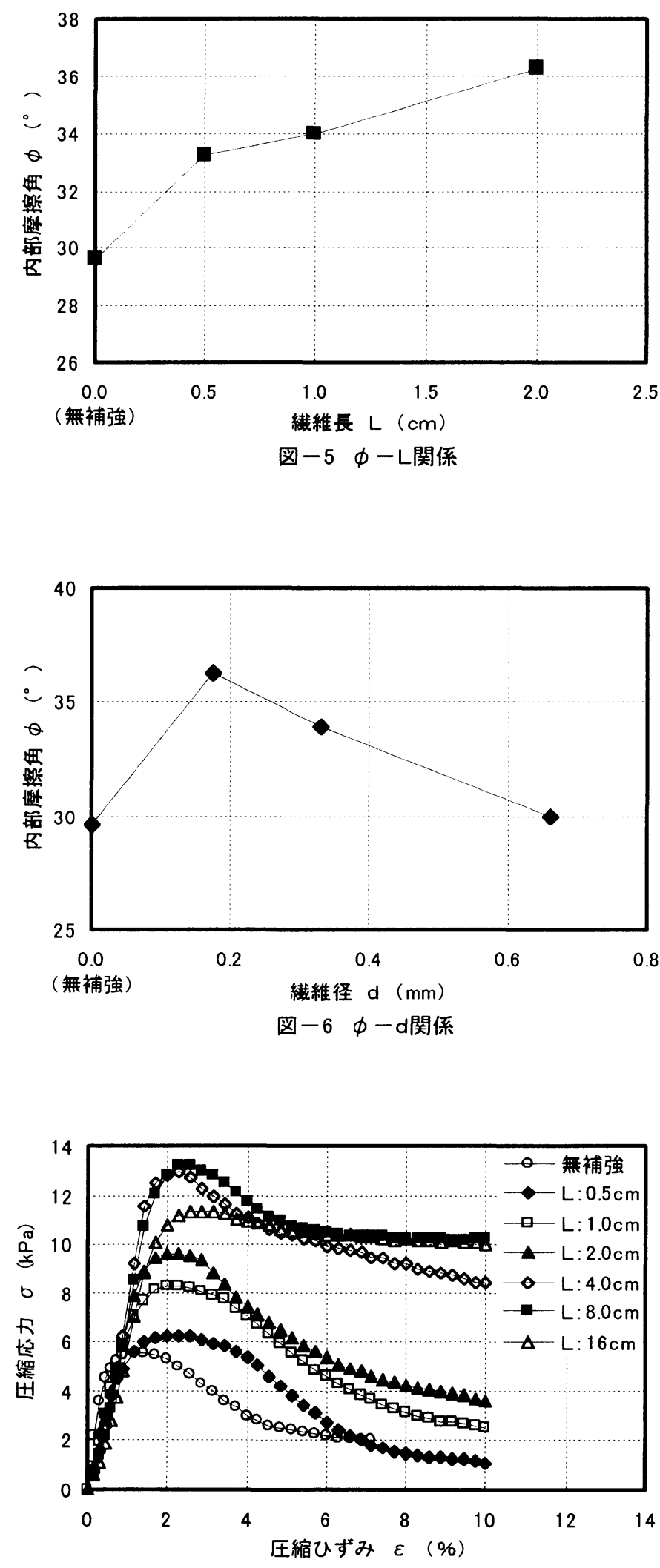

図一7 $\sigma-\varepsilon$ 曲線(繊維長の影響) 
にくくなることが考えられる。

\section{$3-2$ 一軸圧縮特性}

図一 7 は繊維長, 図一8は繊維径の違いによ る圧縮応力一圧縮ひずみの関係を示したもので ある。

図ー 7 より, 纎維長が大きくなるに伴い, 圧 縮強度は増加する傾向が認められる。これは, 繊維長が長くなるに伴い, 瀻維同士による絡み 合い抵抗領域が供試体内に拡大寸るためである と考えられる。また, 今回使用した試料土 $(S+$ K）は, 繊維混入により土質性状として粘り強さ が付与され，補強効果が得られたと考えられ る。

図ー8より, 纎維径が小さくなるに伴い圧縮 強度は高くなる傾向が認められる。これは, 緎 維径が細いものは, 太いものと比べて柔らかく 柔軟性に優れ繊維が砂と絡みや寸く，供試体内 で土粒子接触との密着性を高補強効果は高ま ると考えられる。また, 今回行った試験では, 混 入率一定であるために繊維径が小さいものほ ど, 繊維の本数が多いために土と均一に混合さ れやすく土粒子と密接に絡み合うためといえ る。

図-9 は繊維長, 図一10は繊維径が異なる場 合の圧縮応力ー繊維長・繊維径の関係を0.5\%〜 8. $0 \%$ の各ひずみ段階ごとに示したものである。

図ー9より，繊維長 $\mathrm{L}: 0.5 \mathrm{~cm} \sim 4.0 \mathrm{~cm}$ まで は, 圧縮応力の増加傾向が見られるが， L: $4.0 \mathrm{~cm}$ 以上繊維長になるとその増加割合が鈍く なり L : $16 \mathrm{~cm}$ たいては下がる傾向が見られた。 これは，繊維長に比例して補強効果が向上寸る が，ある一定以上の繊維長になると絡み合いに よる補強増分が得られなくなったと考えられ る。

図-9, 図一-10より，0.5\%ひずみ時（初期 段階）においては繊維混入による補強効果は得
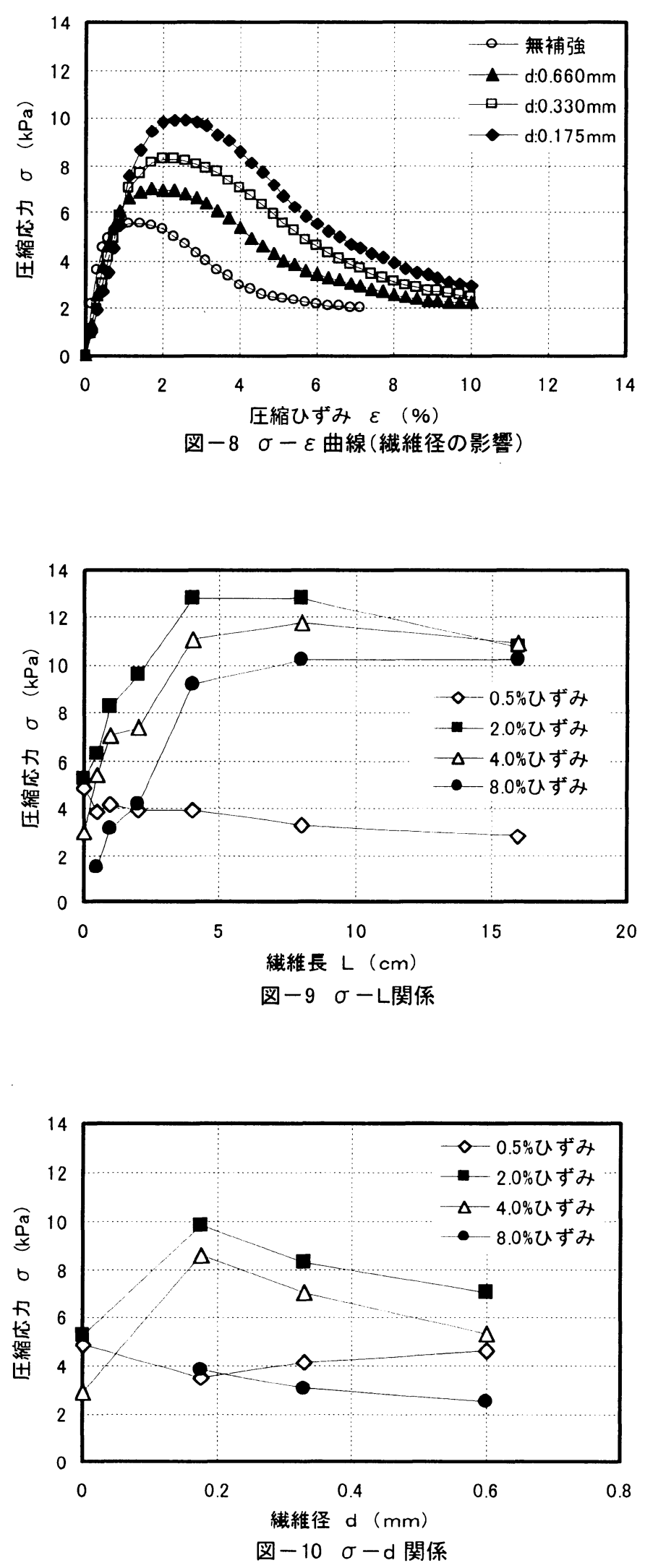
られていないことから，初期の段階において は，繊維の補強作用は発揮されておらず，ひず み約 $2 \%$ 時に最大圧縮応力を示している。

図一 11, 図一 12 は, 縦軸に圧縮応力のピー ク後の強度減少率 $\mathrm{T}(\mathrm{T}=($ 最大圧縮応力一残留圧 縮応力）／最大圧縮応力）, 横軸に圧縮ひずみ $\varepsilon$ をとり, 纎維の残留強度八の影響を示してい る。

図ー 11 より, 繊維長が大きいものほど強度減 少率が小さく, 残留強度が高くなる傾向が見ら れた。繊維長 L $: 0.5 \mathrm{~cm} \sim 2.0 \mathrm{~cm}$ においては, 強 度減少率がひずみ $4 \%$ 時と $10 \%$ 時を比心゙ると約 $50 \%$ 減少率が認められるのに対し, 纎維長 $\mathrm{L}: 4.0 \mathrm{~cm} \sim 16 \mathrm{~cm}$ においては, 約 $10 \%$ の強度低 下にとどまっており，繊維が大きいものほど残 留強度の保持率が高いことが分かる。これは, 繊維長が大きいものほど, 繊維同士または繊維 と砂との絡み合いにより，せ九断破壊の抵抗に 有効的に作用しているため, 変形破壊に対して 勒性が増し補強効果が得られたと考えられる。

図ー12より，いずれの繊維径においてもほぼ 同様な傾向がみられ, 繊維径は, 残留強度に影 響を及ぼさないことが分かる。これは，せん断 面に対して, 繊維径の影響はなく残留強度は繊 維長の影響を受けるためである。今回, 繊維径 の影響を調バる試験においては繊維長 $\mathrm{L}: 1.0 \mathrm{~cm}$ であるため, 残留強度はほとんど同程度の值に なったと考えられる。
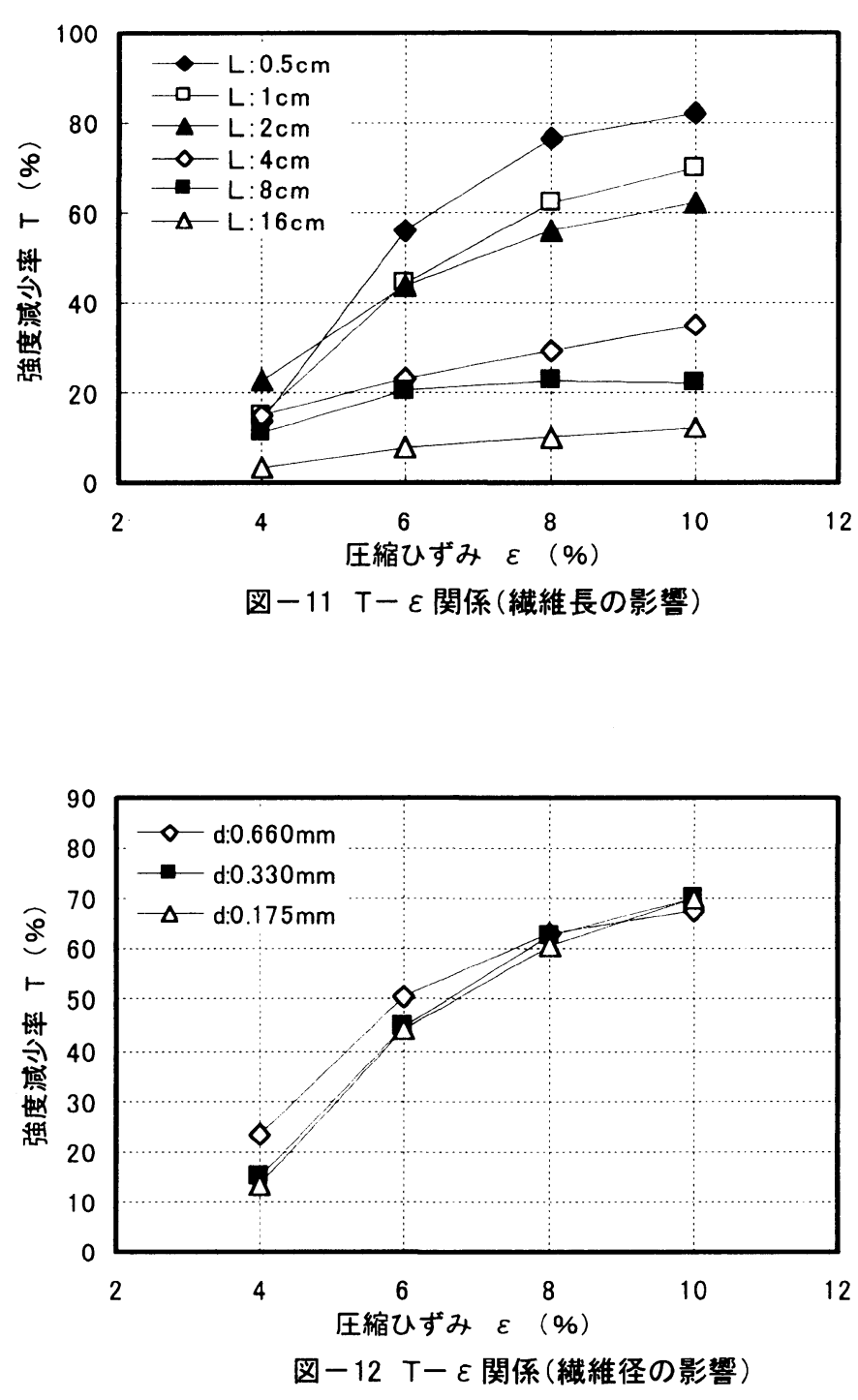

\section{4 結論}

本研究で得られた結論を以下に示す。

（1）繊維径が一定の場合，繊維長が大きくなるに伴い，補強効果は高くなる。

（2）混入率一定条件では, 繊維径が小さいものほど繊維の本数が増すため分散性が高まり, 補強効果 が高い。

（3）一軸圧縮試験において, 繊維長が大きくなるに伴い補強効果が得られるが, ある一定以上の纎 維長になるとその増加幅は緩やかになる傾向が見られた。 
（4）一軸圧縮試験による残留強度においては, 繊維長に左右されるが，纎維径の影響は受けない。

【謝辞】本研究を行うにあたり，本学学生渡辺太一，天粕和彦，細田智也君の協力を得た。ここに深甚の 謝意を表します。

\section{【参考文献】}

（1）プラダン テージ, 今川竜二: 短繊維混合土の排水せん断特性, 第 33 回地盤工学研究発表会講演集 PP. 2371-2372, 1998. 